\title{
CASE COMMENT: RODRIGUEZ AND ASSISTED SUICIDE IN CANADA
}

\section{IAN DUNDAS}

\section{INTRODUCTION}

Life cannot be reasonably regarded as an unconditioned good, but rather as something which is valuable only if one has the possibility of wanted experience.... If continuing to live requires unwanted experiences which overbalance the wanted experiences, then that person has a good reason to die. ${ }^{1}$

Euthanasia ... constitutes a major breach against laws of humanity. It could in fact signify the abandoning of the very concept of democracy and relegate us to a new world and society which will be totalitarian.

This is a gradual return to the law of the jungle... Darwinian principles, applied to human beings are truly the starting point of a process of decline and decadence which will lead to the end of human civilization. $^{2}$

Abortion, capital punishment, euthanasia - issues that compel the individual to examine personal value systems. Few matters can polarize the citizenry to such an extent, and invariably pleas for analytical discussion elicit no more than emotional retorts. In the 1960s and 1970s capital punishment was the issue in vogue, while in the 1980s, national attention switched to abortion. Now, in the 1990s, euthanasia has begun to take its place on the national stage; once again we are asked to cast off the apathetic anchors of indecision and decide whether decriminalizing euthanasia conforms with Canadian ethical and legal standards.

Recently, the difficulties of Sue Rodriguez have thrust the issue of euthanasia into the fore of popular debate. The circumstances surrounding Ms. Rodriguez' legal challenges $^{3}$ have been widely publicized. Ms. Rodriguez sought the option of legal physician assisted suicide in case her disease, amyotrophic lateral sclerosis (ALS), prevented her from completing this act independently. Ms. Rodriguez claimed her rights under the Charter ${ }^{4}$ were violated by the criminal prohibition of assisted suicide. ${ }^{5}$

B.Comm. (Calgary), LL.B. (Alberta). Currently articling with the law firm Blake, Cassels \& Graydon in Calgary. This case comment won first prize in the 1994 William Morrow essay contest.

A. Browne, "Assisted Suicide and Active Voluntary Euthanasia" (1989) 2 Can. J.L. Juris. 35 at 54.

$2 \quad$ P. Schepens, M.D., "Euthanasia: Our Own Future" (1988) 3 Issues L. \& Med. 371 at 384.

3 Rodriguez v. British Columbia (Attorney General), [1993] 3 S.C.R. 519 [hereinafter Rodriguez].

4 Canadian Charter of Rights and Freedoms, Part I of the Constitution Act, 1982, being Schedule B of the Canada Act, 1982 (U.K.) 1982, c. 11 [hereinafter Charter]. 
In its first decision concerning euthanasia, ${ }^{6}$ the Supreme Court of Canada rejected Ms. Rodriguez' claim, thus ending her bid for assistance in ending her life.

Euthanasia describes a broad range of activities and conjures many different meanings. The focus of this comment will be restricted to euthanasia as it is manifest in voluntary physician assisted suicide. The comment will weigh the legal and ethical implications that accompany the legalization of euthanasia. After analyzing the pronouncement of our highest court, the comment shall discuss how this decision will affect the future of voluntary death in Canada.

\section{RODRIGUEZ v. BRITISH COLUMBIA (ATTORNEY GENERAL)}

An extensive treatise on Canadian constitutional law is beyond the scope of this article. However, to appreciate the legal status of assisted suicide in Canada, one must begin with an examination of the Rodriguez decision. Before turning to the separate judgments, one must understand the breadth of the problem presented to the Court. Although primarily concerned with the constitutionality of s. 241(b), the Court was forced to attempt the daunting task of interpreting the extent to which the right of selfdetermination ${ }^{7}$ is protected under the Canadian Constitution. The complexity of this issue led the Court to lengthy and conflicting judgments.

\section{A. THE MAJORITY DECISION}

Per: La Forest, Sopinka, Gonthier, Iacobucci and Major JJ. The majority judgment provided two principal findings of law:

i) s. 241(b) engages the Appellant's security interest under s. 7 of the Charter. ${ }^{8}$ However, it does not contradict principles of fundamental justice, and therefore does not violate the Constitution.

ii) Assuming the equality protection of s. 15(1) of the Charter is affected, any violation of rights is saved as a reasonable limit prescribed by law under $\mathrm{s} .1$ of the Charter. ${ }^{10}$

Sopinka J. for the majority authored a legalistic and well reasoned judgment which involved extensive policy analysis. His central concern was whether a societal interest in the preservation of life should prevail over an individual's personal security interest. He concluded that, even though society believes life sacrosanct, this belief does not

\section{Supra note 3.}

Some argue that suicide for any reason is paradoxical to notions of self-determination (see Browne, supra note 1 at 43 ) while others claim the right to determine the manner and time of death is the ultimate expression of individual autonomy (see E. Young, "Assisting Suicide: An Ethical Perspective" (1987) 3 Issues L. \& Med. 281 at 282). This debate will be considered more fully further in the comment.

- [Hereinafter s. 7]. The Appellant, Ms. Rodriguez, was appealing a decision of the British Columbia Court of Appeal.

[Hereinafter s. 15(1)].

[Hereinafter s. 1]. 
create absolute rules with respect to the preservation of life." The societal interest cannot be considered in isolation, but must be balanced against the individual's right to exercise autonomy. ${ }^{12}$ Unrestricted intrusions by the state into the domain of the individual will not remain unchallenged, since individuals must have latitude to make quality of life decisions, in the furtherance of personal autonomy. ${ }^{13}$

However, despite a recognition of the individual's interest, the Court maintained that the societal interest in the preservation of life is too great to be subrogated by an individual's plea for autonomy. The danger of the uncontrolled expansion of euthanasia, coupled with the high potential for abuse are sufficient to override any security interests that may be violated. ${ }^{14}$

After dispensing with s. 7, the Court quickly dismissed the appellant's two remaining grounds of contention. First, since no state "interest" existed, the Court ruled that s. 12 of the Charter was not violated. Second, to avoid an extensive s. 15(1) analysis, the majority dealt with equality rights under s. 1 . In conducting a s. 1 analysis, the Court determined that any s. 15(1) violations were justified in order to advance the state interest in preserving life.

Overall, the majority demonstrated empathy and compassion for Ms. Rodriguez, but felt it could not allow her application because of adverse societal effects.

\section{B. McLACHLIN J. (DISSENT)}

Per: L'Heureux-Dube' and McLachlin JJ. McLachlin J. at 624, 628 confined her

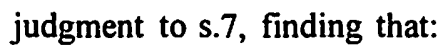

s. 241(b) violates the appellant's security interest under s. 7. This violation is not within the principles of fundamental justice, and is not saved as a reasonable limit prescribed by law under $\mathbf{s} .1$.

In many respects, McLachlin J.'s dissent is consistent with the majority decision. Both found that notions of the sanctity of life must be tempered with concerns regarding quality of life. However, McLachlin J. was of the view that principles of

Supra note 3 at 595 .

Ibid. at 593 . Sopinka J. refers to autonomy in the non-religious sense. See also M. Strass, "The Argument for Autonomy" (1987) 65 N.C.L.R. 315 at 337 referring to R. Dworkin. Dworkin defines autonomous action as being critical to notions of personhood. He claims that autonomy is linked conceptually to "notions of creativity, of adherence to principle, of responsibility."

In considering the scope of the rights contained in s. 7, the Court referred with favour to the approach taken in R. v. Morgentaler, [1988] 1 S.C.R. 30; and Reference re ss. 193 and $195.1(1)(c)$ of the Criminal Code (Man.), [1990] 1 S.C.R. 1123.

14 Supra note 3 at $600-601,613-614$. The Court held that because a societal interest was being advanced, principles of fundamental justice were not violated. Supra note 3 at 47 . Conducting a policy analysis within $\mathbf{s .} 7$ was rejected by the minority when an arbitrary right violation took place. The minority felt that the balancing test should occur during a s. 1 analysis. However, the different approaches are somewhat academic, because even if the majority had not employed a policy test within s. 7, the same arguments would have surfaced during a s. 1 test with a similar result. 
fundamental justice were violated because of the arbitrary manner in which s. 241(b) impacted the appellant. Further, the provision could not be saved under s. 1, as the violation was not minimally intrusive. ${ }^{15}$ McLachlin J. rejected the dangers of the slippery slope because current provisions of the Criminal Code essentially ensured the protection of life. In addition, McLachlin J. felt it was possible to design a legislative scheme to address the problem of involuntary consent.

\section{LAMER C.J. (DISSENT)}

Lamer C.J. at 580 approached his decision from the perspective of s. 15(1):

s. 241(b) violates the Appellant's equality rights as protected by s. 15(1). The violation is not saved as a reasonable limit prescribed by law under $s .1$.

Lamer C.J. focused on the appellant's right to equal treatment under the law. He found that the effect of s. 241(b) was to deprive the appellant of an advantage available to others, which resulted in a s. 15(1) violation. ${ }^{16}$ This violation could not be saved by s. 1 because it was not minimally intrusive. The Chief Justice dismissed the slippery slope argument as "speculative" and felt that speculative grounds were not sufficient to justify a Charter violation. ${ }^{17}$

\section{CORY J. (DISSENT)}

Cory J. at 629 dissented from the majority decision, stating that "s. 241(b) violates the Charter for the reasons stated by both McLachlin J. and Lamer C.J."

While Justice Cory's non-legalistic dissent did not add significantly to the constitutional fund of knowledge, he did provide an interesting comment. He stated that life and death are intrinsically inseparable, and therefore any protections offered for "life" must necessarily apply to "death". Since s. 7 of the Charter protects individual dignity during life, it must also protect dignity at the end of life. ${ }^{18}$

\section{E. JUDGMENT SUMMARY}

Although a five to four decision might suggest that the Supreme Court Justices approached the case in dissimilar fashions, the author suggests that essentially each decision turned on the basis of policy concerns.

In conducting the s. 1 test outlined in R. v. Oakes, [1986] 1 S.C.R. 103, McLachlin J. found that the objective of the legislation was to prevent murder committed under the guise of voluntary assisted suicide.

Lamer C.J. conducted the test to determine as. 15(1) violation outlined in Andrews v. Law Society of British Columbia, [1989] I S.C.R. 143. He found that access to suicide is a benefit. Since s. 241 (b) limits the appellant's access to this benefit at law, and since this distinction is solely the result of the appellant's physical characteristics, s. 15(1) is violated. 
The Charter is a wide and expansive tool. It equips the judiciary with powers previously unknown outside legislative circles. ${ }^{19}$ To suggest that the decision was simply the product of legal research demonstrates a naïvete toward the Canadian legal system. It was well within the Court's prerogative to uphold or strike down s. 241(b) on the basis of policy concerns. The comment will now focus on the issues of policy that emerge from this decision and discuss how the Supreme Court's interpretation conforms with contemporary legal and ethical jurisprudence.

\section{PERSONAL AUTONOMY AND THE PUBLIC INTEREST}

Every human being of adult years and sound mind has a right to determine what shall be done with his own body. 20

...human beings must always be treated as an end in themselves and should never be treated as a means to an end. The sanctity of human life is a paramount value. ${ }^{21}$

Although a pillar in the foundation of our common law heritage, ${ }^{22}$ personal autonomy has never been considered an inalienable right. ${ }^{23}$ Majoritarian interests pertaining to the preservation and promotion of life $\mathrm{f}^{24}$ have always been considered legitimate restrictions on individual autonomy.

Ms. Rodriguez proposed that because her quality of life was severely impaired, state interests must succumb to her personal autonomy rights. ${ }^{25}$ The notion that an individual should be free to pursue their own ends, so long as they do not harm others is a concept central to our libertarian tradition. ${ }^{26}$ This philosophy forms the central premise for the argument that, in the furtherance of autonomy, individuals should have the freedom to terminate their own lives. ${ }^{27}$ Advocates maintain that life is only "one

It is beyond the scope of this comment to consider whether the judiciary should impose selfconstraints when moving into the realm of policy. However, at the British Columbia Court of Appeal and the Supreme Court, the inappropriateness of "judicial legislation" was cited as one reason to uphold the statute.

Justice Cardozo in Schloendorff v. Society of New York Hospital, 105 N.E. 92 at 93 (N.Y., 1914) referring to an individual's right to consent to medical treatment. The quote is oft cited as one of the starting points for judicial recognition of the right to self-determination with respect to medical treatments, see J. Crowley, "To Be or Not To Be: Examining the Right to Die" (1992) 18 J. Legisl. 347 at 348.

V. Rosenblum, J.D. \& C. Forsythe, J.D., "The Right to Assisted Suicide: Protection of Autonomy or an Open Door to Social Killing?" (1990) 6 Issues L. \& Med. 3 at 21.

R. Risley, "Voluntary Active Euthanasia: The Next Frontier: Impact on the Indigent" (1992) 8 Issues L. \& Med. 361 at 368.

D. Gibson, "Perimortal Initiatives: Issues in Foregoing Life-Sustaining Treatment, Suicide and Assisted Suicide" (1987) 3 Issues L. \& Med. 29 at 32-35.

S. Mojica \& D. Murrell, "The Right to Choose - When Should Death be in the Individual's Hands?" (1991) 12 Whittier Law Rev. 471 at 499.

Supra note 3.

Risley, supra note 22 at 368.

A. Koury, "Physician Assisted Suicide for the Terminally Ill: The Ultimate Cure?" (1990) 33 Ariz. L. Rev. 677 at 691 . This notion is also the impetus behind several euthanasia movements, including the Hemlock Society in the United States. 
among a number of goods including individual autonomy" and "human dignity", ${ }^{28}$ and cannot be considered in isolation. Calls for autonomy "do not have to be antithetical to arguments defending the special value of human life." ${ }^{129}$

Other proponents of voluntary active euthanasia have embraced these theories. They have posited that the state interest and the right to personal autonomy move along a dynamic continuum; the state interest weakens as the individual's quality of life diminishes. ${ }^{30}$

Regardless of the intuitive appeal, these arguments have not received unanimous support. Scholars who reject personal autonomy as a valid justification for determining ones' own life tend to present their critiques from two separate perspectives: first, persons who oppose euthanasia on religious grounds, and second, persons who suggest there must be limits on the rights contained within the ambit of autonomy.

\section{RELIGIOUS OPPOSITION}

There are those who believe Judeo-Christian tenets forbid suicide in all forms. Life is a gift from God, they insist, and cannot be terminated by mere human beings. ${ }^{31}$ Even extreme suffering is not accepted as a valid justification to overcome the religious taboo associated with suicide. Those who are particularly "devoted" suggest that suffering is in some respects an experience to be cherished and not dreaded. ${ }^{32}$ The argument that religious grounds should prevent euthanasia was not considered in Rodriguez and will not be considered further in this comment. In Canada, religion is considered a personal experience, a belief so firmly entrenched in Canadian culture that it has been constitutionalized in s. 2(a) of the Charter. The protection afforded by this section prevents any person from foisting their religious beliefs upon another. Given the constitutional shield of s. 2(a), it is counter-intuitive to suggest that a legal right to voluntary assisted suicide could, in any way, be influenced by religious grounds.

\section{AN AUTONOMOUS RIGHT TO DO A WRONG}

The second line of reasoning rejecting the individual's right to assisted suicide holds that the right to autonomy does not extend to assisted suicide. Supporters of this theory contend that a carte-blanche approach to rights claimed under the guise of personal autonomy is unjustifiable; that individuals do not have the right to do to themselves that which is intrinsically wrong. ${ }^{33}$ The right to autonomy only allows individuals to "legislate" for themselves on the same basis that they "legislate" for others. ${ }^{34}$ Since it

Rosenblum, supra note 21 at 20.

R. Vance, "Autonomy's Paradox: Death, Fear and Advance Directives" (1991) 42 Mercer L. Rev. 1051 at 1053.

In Re Quinlan, 335 A.2d 647 at 664.

Gibson, supra note 23 at 32 . See also Browne, supra note 1 at 41.

G. Coleman, "Assisted Suicide: An Ethical Perspective" (1987) 3 Issues L. \& Med. 267 at 276.

Rosenblum, supra note 21 at 21 .

N. Arkes, Ph.D., "'Autonomy' and the 'Quality of Life': The Dismantling of Moral Terms" (1987)

2 Issues L. \& Med. 421 at 429. 
is logically inconsistent to detach autonomy from its moral foundation, ${ }^{35}$ one cannot claim the right to assisted suicide simply in the name of personal autonomy.

The Achilles' heel of this theory is the presumption that voluntary assisted suicide is never justifiable. This proposition fails to explain why the right to self-determination cannot encompass a quality of life component. It would be a monumental endeavour to reach a consensus with respect to the scope of when suicide should be justified. However, this does not logically lead to the conclusion that there are no grounds to allow an individual to terminate her life. ${ }^{36}$

The argument in favour of voluntary assisted suicide as the ultimate expression of personal autonomy has an intrinsic validity. It cannot therefore be cast aside by an abstract state interest that encases the individual. A state interest in "beneficence" 37 towards the individual must always consider, and usually defer, to the individual's autonomy interest. ${ }^{38}$ However, this in-and-of itself is not a sufficient basis to conclude that voluntary assisted suicide should be legalized. Without question, the state has a legitimate interest in the protection of life. This interest is particularly strong in the case of vulnerable persons such as the very young, the weak and the elderly. Therefore, an individual's autonomy interest cannot be the sole determinative factor if it can be demonstrated that voluntary assisted suicide may have a negative effect on individuals other than the terminal patient. Autonomy has never been allowed to be determinative when public good has been violated. ${ }^{39}$

All Supreme Court justices in Rodriguez supported this proposition. Implicit in the majority decision, and explicit in each dissent, is the principle that if the rights of persons other than the applicant will be impaired, the state has legitimate authority to interfere with an individual's prerogative. The comment will now consider negative societal effects that might occur because of the legalization of assisted suicide.

\section{THE WEDGE}

It started with the acceptance of the attitude, basic in the euthanasia movement, that there is such a thing as life not worthy to be lived.

Ibid. at 428.

The scope of these "valid" reasons is a key point of contention, even amongst supporters of voluntary assisted suicide. Most agree that certain reasons can be classified as frivolous. However, once any exception to the absolute sanctity of life has been made, it is very difficult to find any other "logical" place to make a distinction. Some have proposed that a valid justification to terminate ones' life exists when "life's purpose" is no longer attainable (see Coleman, supra note 32 at 270-271). Others state that determining a "purpose" is simply too subjective. It is precisely this problem that plagued the majority in Rodriguez.

Young, supra note 7 at 283.

Browne, supra note 1 at 55 .

Coleman, supra note 32 at 268. 
...But it is important to realize that the infinitely small wedged-in lever from which this entire trend of mind received its impetus was the attitude toward the nonrehabilitable sick. ${ }^{40}$

Those espousing this view, view our society incapable of drawing the line at a specific kind of conduct.

...If the argument were true, then legal abortion should by now have led to legal infanticide. ${ }^{41}$

The wedge or slippery slope theory provides perhaps the most compelling argument against legalizing voluntary assisted suicide. Proponents claim that making any exception to our belief in the absolute protection of life by allowing assisted suicide will inevitably result in non-voluntary euthanasia. ${ }^{42}$

It is the author's belief that this issue, above all others, split the court in Rodriguez. The majority felt the danger of inadvertently moving away from a very limited practice, to one allowing non-voluntary active euthanasia was simply too grave. ${ }^{43}$ Conversely, the minority dismissed the danger of expansion as being merely speculative. ${ }^{44}$

The central thrust of the slippery slope theory holds that in permitting this first step, society accepts that life may have a diminished quality. There is then no rational way to limit the expansion of the practice. ${ }^{45}$ As Yale Kamisar states, "the legal machinery initially designed to kill those who are a nuisance to themselves may some day engulf those who are a nuisance to others. ${ }^{146}$ Opponents of assisted suicide suggest that much of the expansion will not be at the insistence of the morally devoid, but rather by those motivated by compassion. ${ }^{47}$ Once the door is opened in the name of reducing suffering, there will be extreme "pressures to expand this compassion" to others who are also suffering, but who may not have terminal illnesses. ${ }^{48}$ Any movement away from a maniacal protection of all life, claim adherents, will result in a paradigm shift in the way society regards life. Thereafter, it becomes exceedingly difficult to refuse requests to "shorten the time of suffering."49 By focusing on the suffering individual

L. Alexander, "Medical Science Under Dictatorship" (1949) 241 N. Eng. J. Med. 39 at 40 . As referred to in P. Derr, Ph.D., "Hadamar, Hippocrates, and the Future of Medicine: Reflections on Euthanasia and the History of German Medicine" (1989) 4 Issues L. \& Med. 487 at 490 . The author refers to the program of non-voluntary euthanasia that resulted in the murder of some 270,000 "useless eaters" by German doctors immediately preceding and during the Second World War.

" C. Smith, "What About Legalized Assisted Suicide?" (1993) 8 Issues L. \& Med. 503 at 514-515.

\section{Ibid.}

43 Supra note 3 at $613-614$.

$4 \quad$ Ibid. at 626.

45 P. Drey \& J. Giszczak, "May I Author My Final Chapter? Assisted Suicide and Guidelines to Prevent Abuse" (1992) 18 J. Legisl. 331 at 339.

46 Y. Kamisar, "Euthanasia Legislation: Some Non-Religious Objections" in A.B. Daming, ed., Euthanasia and the Right to Death (London: Owen, 1969) 87 as referred to in ibid. at 336.

${ }^{4}$ N. Dickey, "Euthanasia: A Concept Whose Time Has Come?" (1993) 8 Issues L. \& Med. 521 at 528. 
and ignoring the dangers inherent in the practice, persons with compassion will feel compelled to legalize assisted suicide. Harsh as it may seem, the plight of the individual is an insufficient justification for assisted suicide since "the institutionalization of euthanasia is so fraught with serious risks....."50

Although many suggest the wedge theory should be dismissed as fearmongering, the author cannot accept such a cavalier rejection. Because of the risk posed to life, the burden lies with proponents of decriminalization, not simply to mock fears, but rather to establish that "opening the doors to assisted suicide will not inevitably lead to the destruction of the powerless in our society." ${ }^{\text {s1 }}$

This task is made especially difficult when the lessons of history are studied. Champions of voluntary assisted suicide spurn as inflammatory any reference to the German experience. They claim political and cultural conditions in Western civilization bear no resemblance to the historical quirk that created the Third Reich. The study of influences that led to the unconstrained euthanasia movement in Germany is beyond the scope of this article. However, one point deserves mention; in 1920, German medicine was unparalleled in terms of technological superiority, and yet unchecked "barbarism"52 was the norm within twenty years. Patrick Derr summarizes the lesson that we must take from the German experience if any movement towards euthanasia is considered:

What makes the administrative mass killings so outstanding is not their numbers, their efficiency, or their cruelty, but the fact that they occurred in an epoch when nobody thought it was humanly or socially possible. Therein lies their deepest lesson. ${ }^{53}$

History demonstrates that a fall down the slippery slope is indeed possible, even for "progressive" nations. If voluntary assisted suicide is legalized, provisions must be in place to ensure that the same desecration of life, and contempt for humanity, does not occur in Canada.

Even though in Rodriguez the Court felt decriminalization could lead to the devaluation of life, the author suggests this need not be the case.

The hypothesis that voluntary assisted suicide could be practiced in Canada without allowing a careen down the slippery slope is based on the following premises.

First, the Canadian Criminal Code has extensive provisions to protect individuals from the clutches of those who would terminate their lives. This includes the continued

so

W. Winslade, "Guarding the Exit Door: A Plea For Limited Toleration of Euthanasia" (1988) 25 Hous. L. Rev. 517 at 517. Referring to an argument by S. Potts in "Looking for the Exit Door: Killing and Caring in Modem Medicine" (1988) 25 Hous. L. Rev. 493 at 499.

s)

s2

53

Gibson, supra note 23 at 33.

Derr, supra note 40 at 488.

Ibid. at 491. Although beyond the scope of this comment, the Dutch experience provides another case study as to the practice of euthanasia in a modern state. See J.H. Van der Maas et al., "Euthanasia and Other Medical Decisions Concerning the End of Life" (1991) 338 The Lancet. 
restriction in s. 241(a) on counselling another to commit suicide, in addition to the multitude of culpable homicide restrictions.

Second, any attempts to practice voluntary assisted suicide should be endorsed only with judicial authorization. ${ }^{54}$ Ardent supporters of individual rights may protest this administrative intrusion into the very private and personal end of life decisions. ${ }^{\text {ss }}$ However, to prevent the abuses that could potentially occur, there simply is no alternative. To ensure consent has been validly obtained, all forms of euthanasia would be prohibited without an express court order, regardless of apparent factors evidencing consent. Any violation of this restriction would have to be met with harsh punishment.

Finally, the practice would, without exception, be restricted to persons with terminal illnesses in advanced stages. For many advocates of voluntary active euthanasia, this restriction is unacceptable and illogical. If we allow persons with terminal illnesses to terminate their lives, why not allow this option for those whose quality of life is severely diminished because of incurable and painful, but not necessarily terminal afflictions? The response is simple; the danger of a plunge down the slippery slope is indeed real. Once limited euthanasia is permitted, the only remaining place for a restriction, one that does not involve entirely subjective quality of life determinations, is where the end of life is quickly approaching we must guard against the peril of an expanding wedge, unless we are willing to accept the risk of creating an entirely new "class of illegitimates"; ${ }^{56}$ persons whose right to, and quality of, life is determined by others.

For the non-terminal patient who desires death, it may be difficult to accept that she should not be provided the option available to the patient with a disease like ALS, simply because her natural life span may be longer. She will not care that the rationale for this decision is to protect an abstract societal interest. She will claim she has the right to dignity, the right to a dignified death, and the right to be free from endless pain. To these cries, an unsatisfactory response is all that is available. We live in a society where life is sacred. Although enlightenment with respect to the promotion of autonomy is dawning, we fear the lessons of history. We fear our nature - we simply do not trust ourselves. Until we can demonstrate that abuse will not take place, our first steps into the fray must be tentative.

\section{DEATH AFTER RODRIGUEZ}

Does Rodriguez provide the definitive answer to the status of assisted suicide in Canada? Is the door now closed to those persons who would partake in this activity, or does the law still offer hope? This section of the comment will attempt to establish

Supra note 3 at 579,629,631. In each of the dissenting judgments, the need for judicial authorization was included as a condition precedent to a legal assisted suicide.

ss The fear is that this administrative step will result in "judges at the bedside." See L. Wardle, "Sanctioned Assisted Suicide: 'Separate But Equal' Treatment for the 'New Illegitimates'" (1987) 3 Issues L. \& Med. 245 at 250. 
that Rodriguez will not prevent the practice of voluntary assisted suicide from continuing in Canada, nor will it curb a growing approval for the legalization of assisted suicide for terminal patients.

Despite criminal prohibition, it is common practice for terminal patients to request their physician help to end their lives. It is also common practice for many physicians to comply with these requests. ${ }^{57}$ There is no reason to suspect that the decision in Rodriguez will have any effect on this practice.

Further, the author proposes that there will be heightened pressure on legislative bodies to reform the law to comport with common practice. To ensure that accessibility to assisted suicide is equal for all terminal patients, not only those with bold physicians.

In his investigation of principles of fundamental justice, Sopinka J. searched for a consensus of public opinion concerning assisted suicide. ${ }^{58}$ The author predicts that public consensus will begin to emerge which will support a limited decriminalization of voluntary assisted suicide.

Advances in medical technology, ${ }^{59}$ an aging population and increases in the number of people infected with the AIDS virus will all contribute to this limited acceptance. These factors are linked by a common thread, each will result in more Canadians being personally affected by difficult end-of-life decisions. Academic pleas that voluntary assisted suicide will symbolically diminish respect for humanity may have wide appeal in the abstract. However, the symbolic quickly becomes less consequential when weighed against the actual fear of pain, and loss of dignity endured by many terminal patients. Academics can continue to bound on intellectual trampolines, debating the dangers of the slippery slope, but real changes in public pinion will be prompted by empathy for persons faced with the challenges of Sue Rodriguez and those like her. ${ }^{60}$

Smith, supra note 41 at 510 . The author claims that 4.2 percent of physicians have helped patients stockpile lethal doses of drug knowing that they might be used in a suicide [source: a survey conducted by the Center for Health Ethics and Policy at the University of Colorado). But in spite of this participation, there have been only twelve prosecutions of assisted suicide in the United States from 1980 to 1991. Supra note 3 at 607-608.

Koury, supra note 27 at 687 "Medical technology has effectively created a twilight zone suspended animation where death commences while life, in some form, continues." See also Crowley, supra note 20 at 353: "It is one of the great unanticipated ironies of modern society that the more capable medical technology becomes at reducing health problems and prolonging life, the more we must decide when to prevent that very same technology from unnecessarily prolonging the process of death." referring to A. Malcolm, "What Medical Science Can't Seem to Learn: When to Call It Quits" The New York Times (23 December 1990) D6.

"Police Urged to Witness Suicide" The [Toronto] Globe and Mail (2 November 1993) Al. Mr. Krickhahn, a patient with ALS, has stated that he plans to commit suicide when his disease enters the final stages. However, because of the decision in Rodriguez, Mr. Krickhahn claims he will have to end his life sooner than he would if he were able to garner assistance. His statement that he will not be able to experience Christmas with his granddaughter because of this decision, will likely have a far greater impact on Canadian opinion that any theoretical appeal to the sanctity of life would have. 
But will this swing in public opinion force changes in the law? The wheels of justice may move slowly, but move they do. All that remains to be seen are the timing and scope of the change.

\section{THE ETHICAL CONUNDRUM}

An issue that was scarcely addressed in Rodriguez was the potential impact that the legalization of assisted suicide would have on the medical profession. Physician participation in any form of euthanasia raises ethical issues pertaining to the role of physicians in society, and legal issues concerning the potential criminal culpability of physicians.

The preceding section has demonstrated that voluntary assisted suicide will take place in Canada. Given the unique societal position that physicians occupy, the mass of requests to "assist" will fall on their shoulders. This section will illustrate that the participation of physicians in the suicide decision process is an undesirable and unfair circumstance.

Physicians frequently face potential legal repercussions when treating terminal patients. Even palliative treatments have legal implications if medications to relieve suffering ultimately result in a shortened life span. ${ }^{61}$ Physicians are placed in the unenviable position of facing criminal sanction for complying with an ever-growing societal request. This creates an unjust situation that will continue as long as there is no legal scheme to allow limited assisted suicides.

A second negative effect resulting from the continued criminalization of assisted suicide is that physicians are forced to partake in a practice antithetic to the role physicians are intended to perform. To allow physicians to commit assisted suicide places "the very soul of medicine ... on trial. ${ }^{.62}$

In primitive cultures, the role of healer and killer was often performed by the same person..$^{63}$ It was not until the insight of Hippocrates that society began to realize that proper health care demanded absolute trust between patient and physician. Until a patient knew that the doctor's only function was to heal, and not to kill, this trust cannot exist. Although the Hippocratic oath now serves primarily as a guide to the art

D. Wilson, "B.C. Suicide Policy Approved by Rodriguez, lawyer says" The [Toronto] Globe and Mail (5 November 1993) Al. The B.C. Attomey General's department issued guidelines as to when prosecutions will take place for assisted suicides and euthanasia. These guidelines were quite lenient. Deaths would be evaluated on a "case by case" basis and prosecutions would not take place unless there was a "public interest" in bringing the case to trial. Deaths resulting from palliative care following proper medical practice will not be subject to prosecution. In addition, in Rodriguez, Sopinka J. was clear that an intention to cause death was a key determination of physician liability. However, in spite of these assurances potential culpability exists. Rosenblum, supra note 21 at 25 citing J. Gaylin et. al., "Doctors Must Not Kill" 259 JAMA 2139 at 2139. 
of medicine ${ }^{64}$ the need for trust is still mandatory. To allow physicians to partake ${ }^{65}$ in any form of assisted suicide jeopardizes this trust and thus violates the primary lesson of Hippocrates.

In addition, because of their skill and close proximity to the dying, physicians are tremendously susceptible to societal pressures to end suffering. As Derr predicts,

If medicine is to avoid playing the role of society's executioner, it must renounce killing utterly and without exception. ${ }^{66}$

The lack of a legal structure to prevent physicians from making the determination as to when assisted suicide will be permitted compromises the medical profession.

The need for assisted suicide clearly exists. Physicians recognize that unless they act, patients not able to end their own lives will be left without any way to avoid a potentially horrible death. ${ }^{67}$ Therefore, many physicians feel it their moral obligation to assist these patients, even if this action compromises the role of healer.

In all dissenting judgments, provision was made to insert the judiciary into the euthanasia process as a check on the discretion that a physician could exercise. This not only to combat the dangers of the slippery slope, but also to protect the integrity of the medical profession. Until the law is changed, judicial intervention so desperately needed will not occur.

\section{CONCLUSION}

The implications associated with limited legalization of assisted suicide are widereaching, and the consequences by no means certain. Situational ethicists can apply their pliable rules and, unhindered by the burdens of rational thought, contentedly approve requests for assisted suicide whenever compassion is engaged. The Supreme Court was not, however, provided this luxury but was forced to balance societal interests against the rights of one suffering individual. Unfortunately for Ms. Rodriguez and those in similar positions, the Court could not dismiss the possibility of negative societal effects resulting from the granting of the appellant's request.

This comment has attempted to demonstrate that, although valid, the desire to protect the societal interest should not defeat the appellant's personal interests. Obviously, a decision to allow physician assisted suicide should not be made lightly, as potential

at Smith, supra note 41 at 516.

65 Obviously physicians must play some role in any assisted suicide legislative scheme. Physicians will have to ensure that applicants are indeed terminal. However, physicians should be removed from the euthanasia approval stage.

66 Supra note 40 at 494.

67 According to palliative physicians, the numbers of truly painful deaths are much lower than euthanasia activists claim. Likely, an increase public awareness as to the effectiveness of palliative care would reduce the requests for assisted suicide. See M. Conolly, "Alternative to Euthanasia: Pain Management" (1989) 4 Issues L. \& Med. 497. 
repercussions are grave. Suicide is an appalling problem in North America, reaching epidemic proportions in some segments of society. ${ }^{68}$ Feelings of isolation and depersonalization are rampant. Legalized assisted suicide cannot be allowed to become a means of coping with those vulnerable persons in society; as a "displacement from dealing with more pressing and genuine life issues." 69 However, in spite of the potential for abuse, we must press on. In order to remain true to our libertarian legacy we must affirm the centrality of individual choice and legalize limited physician assisted suicide.

69 J. Richman, "Sanctioned Assisted Suicide: Impact on Family Relations" (1987) 3 Issues L. \& Med. 53 at 56. 